greatest number of issues difficult for students to quickly understand, on several of which we will try to give an exhaustive comment.

Key words: combinatorics, problem, education institution, element of combinatorics, conditions of existence

удк 373.3.015.31:502/504]:37.064.1

\author{
Алла Колишкіна \\ Сумський державний педагогічний \\ університет імені А. С. Макаренка \\ ORCID ID 0000-0001-9598-1830 \\ Катерина Врадій \\ Сумський державний педагогічний \\ університет імені А. С. Макаренка \\ ORCID ID 0000-0003-2991-7771 \\ DOI 10.24139/2312-5993/2019.08/086-098
}

\title{
ВИКОРИСТАННЯ ІГРОВИХ ТЕХНОЛОГІЙ У ФОРМУВАННІ ЕКОЛОГІЧНО ДОЦІЛЬНОЇ ПОВЕДІНКИ УЧНІВ ПОЧАТКОВИХ КЛАСІВ
}

у статті розв'язується проблема екологічного виховання учнів початкових класів. Мета дослідження полягає в обгрунтуванні ефрективності використання ігрових технологій у формуванні екологічно дочільної поведінки учнів початкових класів. Для досягнення мети публікації використано методику дослідження рівнів екологічної поведінки учнів початкової школи у природі, що складається з таких компонентів: 1) створення уявних ситуацій за допомогою серій завдань; 2) створення реальних ситуацій вибору взірия поведінки учнів початкової школи в природі; 3) спостереження за поведінкою учнів у природі. Розроблено змагальні, рольові та імітаційні екологічні ігри, що базуються на навчальному матеріалі, запропонованому шкільною програмою. Доведено, що гра екологічного змісту сприяє реалізації поведінкового потенціалу дитини щодо природи, забезпечує осмислення власної діяльності у природі. Перспективи подальщих наукових розвідок пов'язані з дослідженням проблеми формування екологічно доцільної поведінки як чинника соціалізації учнів початкової школи.

Ключові слова: екологічно дочільна поведінка, екологічне виховання, дидактичні ігри, рольові екологічні ігри, імітаційні екологічні ігри, учні початкової школи, рівні екологічної поведінки, поведінка.

Постановка проблеми. Екологічні проблеми в наш час набули глобального характеру, досить гостро вони відчуваються і в Україні. Вирішення таких проблем відбувається на різних рівнях - державнополітичному, економічному, науково-технічному, культурно-освітньому. Вагомим у цьому зв'язку постає саме культурно-освітній чинник, адже основні причини екологічної загрози пов'язуються з антропоцентричною свідомістю людей, з їх переважно споживацьким ставленням до природи, стилем діяльності й поведінки в довкіллі. Особливе місце в системі екологічної освіти та виховання належить початковій школі. Саме цей 
період у житті дітей сприятливий для усвідомлення себе невід'ємною часткою природи, своєї ролі та значущості в збереженні її цілісності.

Важливість екологічного виховання особистості означена в Законі України «Про освіту», «Концепції екологічної освіти України». «Основні орієнтири виховання учнів 1-11 класів загальноосвітніх навчальних закладів» серед системи загальнокультурних і громадянських цінностей виділяють ціннісне ставлення до природи, розкривають його сутність та специфічні вікові особливості, тематику виховних заходів відповідно віку. Державний стандарт початкової загальної освіти серед ключових компетентностей, якими мають оволодіти учні нової української школи, виокремлює екологічну компетентність.

Аналіз актуальних досліджень. Наукові підходи до екологічного виховання в сучасних умовах розроблені в дослідженнях А. Захлєбного, І. Звєрєва, Г. Пустовіта, у працях яких висвітлені концептуальні засади досліджуваного та запропоновані відповідні методики.

Теоретичним і методичним аспектам екологічного виховання школярів, формуванню культури екологічної поведінки, екологізації освітнього простору, екологічної компетентності, різним аспектам поведінки в довкіллі присвячені наукові доробки В. Вербицького, О. Колонькової, О. Пруцакової, Н. Пустовіт, О. Шевчук.

Психологічним підґрунтям формування екологічно доцільної поведінки $€$ роботи К. Абульханової-Славської, І. Беха, О. Леонтьєва, А. Петровського, С. Рубінштейна, у яких обґрунтовується, що основою поведінки є вчинки, у яких формуються й виявляються позиція та моральні переконання особистості. Розглядаючи поведінку як системне утворення, учені виділяють потребнісно-мотиваційний, операціональний, інформаційний, регуляторний компоненти.

У працях І. Беха, Л. Божович, В. Давидова, І. Зимньої, Г. Костюка, Д. Ельконіна визначається, що молодший шкільний вік сприятливий для формування екологічно доцільної поведінки, оскільки в цьому віці відбуваються значні зміни в усій психічній сфері дитини. Протягом усього молодшого шкільного віку дитина навчається керувати своєю поведінкою, протіканням психічних процесів. Поведінка молодшого школяра психологічно обумовлена вибором, залежить від оцінки своєї й чужої поведінки, наявності практичних навичок поведінки. Серед основних умов, які забезпечують формування самоконтролю поведінки молодших школярів, $€$ формування навичок моральної поведінки і мотиваційної сторони самоконтролю; прогнозування моральної поведінки $є$ центральним компонентом у структурі моральної саморегуляції поведінки молодших школярів. Участь у різних видах екологічної діяльності молодшого школяра, зокрема в ігровій - сприяє формуванню вмінь та навичок екологічно доцільної поведінки, відпрацюванню поведінкових стереотипів. 
Отже, теоретичний аналіз свідчить, що в молодших школярів $\epsilon$ необхідні передумови формування екологічно доцільної поведінки. Однак, чимало школярів у виборі дій і вчинків у природі керуються, переважно, емоційними імпульсами, прагматичними інтересами, мотивами наслідування й самоствердження, а не раціональними цілями, пізнавальними та естетичними потребами, гуманістичними і природоохоронними мотивами. Більшість учнів намагаються дотримуватися правил поведінки в природі лише за умови контролю з боку дорослих. Крім того, має місце невідповідність між екологічними знаннями учнів та поведінкою у природі, що свідчить про відсутність переконань та обумовлено особливостями суб'єктивного ставлення до природи.

Мета статті полягає в обгрунтуванні ефективності використання ігрових технологій у формуванні екологічно доцільної поведінки учнів початкових класів.

Методи дослідження. Вивчення стану сформованості екологічно доцільної поведінки здійснювалось у ході експериментального дослідження, у якому взяли участь 282 учня початкових класів та 15 учителів-класоводів початкової школи.

Ураховуючи структуру та особливості поведінки учнів у природі, розроблено методику дослідження рівнів екологічної поведінки учнів початкової школи у природі, що складається з таких компонентів:

1) створення уявних ситуацій за допомогою серій завдань, спрямованих на з'ясування рівня екологічної поведінки учнів початкової школи за критеріями унормованості і спрямованості;

2) створення реальних ситуацій вибору взірця поведінки учнів початкової школи в природі, спрямованих на з'ясування рівня екологічної поведінки за критерієм активності;

3) спостереження за поведінкою учнів у природі в ситуаціях, що виникали спонтанно.

Перша серія завдань спрямована на з'ясування рівня екологічної поведінки учнів початкової школи у природі за критерієм унормованості, показниками якого $є$ знання про норми та правила поведінки в природі, людину як частину природи, причинно-наслідкові зв'язки у природі, необхідність збереження природи; оцінка дій та вчинків у природі інших і власних.

Друга серія завдань спрямована на з'ясування рівня екологічної поведінки учнів початкової школи у природі за критерієм спрямованості, показниками якого є емоційно-ціннісне ставлення до природи, що виявляється у творчих, пізнавальних, естетичних потребах взаємодії з природою як рівнозначною цінністю, гуманістичних мотивах і цілях екологічної діяльності, сформованості внутрішніх регуляторів екологічно доцільної поведінки; усвідомлення відповідальності за результати своєї поведінки в природі. 
Третя серія завдань спрямована на з'ясування рівня екологічної поведінки учнів початкової школи у природі за критерієм активності, показниками якого $€$ дії та вчинки щодо збереження та примноження природи, навички і звички практичної природоохоронної діяльності. Екологічно доцільні дії та вчинки учнів початкової школи визначалися в реальних ситуаціях екологічного змісту.

Рівень екологічної поведінки учнів початкової школи у природі визначався відповідно до кожного завдання за відкоригованою формулою Г. Вітцлака (Бобик та ін., 2007, с. 370):

$$
K=\frac{R \times 100 \%}{N}
$$

Де, К(\%) - коефіцієнт - відсоткове співвідношення балів показників;

$\mathrm{R}$ - кількість реальних балів за виконання завдання ( $\epsilon$ змінною величиною);

N - постійна величина, що становить максимальну кількість балів за виконане завдання.

Середній коефіцієнт виконання всіх завдань, який отримувався способом поділу суми коефіцієнтів кожного виконаного завдання на їх кількість, засвідчував рівень екологічної поведінки учнів початкової школи у природі:

80- $100 \%$ - екологічно доцільний;

50-80\% - екологічно ситуативний;

30-50 \% - прагматичний;

нижче 30 \% - екологічно недоцільний.

Виклад основного матеріалу. Вважаючи під «екологічно доцільною поведінкою» учнів початкової школи дії та вчинки під час безпосередньої й опосередкованої взаємодії з природою, пов'язані між собою ціллю збереження природи, зумовлені характерним для учнів початкових класів непрагматичним суб'єкт-суб'єктним ставленням до об'єктів природи або зовнішньо унормовані дорослими (учителем, батьками) (Сбруєва, Колишкіна, 2018, с. 242), зупинимос на характеристиці її рівнів, що служать базою для проведення експериментального дослідження.

Екологічно доцільний рівень, характерний для учнів, які мають ґрунтовні знання про об'єкти природи своєї місцевості, норми та правила поведінки в природі, усвідомлюють зв'язки в природі, розуміють цілі екологічної поведінки. Для поведінки таких учнів притаманне систематичне прагнення до збереження об'єктів природи; вони отримують задоволення від спілкування з об'єктами природи, ставляться до них як до суб'єктів взаємодії. Такі учні активно виявляють позитивні емоції щодо природи та стійкий інтерес до природних об'єктів. Для учнів характерні вміння та навички, спрямовані на збереження природи, безпосередню участь у примноженні природних об'єктів; свідоме зменшення витрат природних ресурсів у повсякденному житті. 
Екологічно ситуативний рівень, характерний для дітей, які добре знають об'єкти природи своєї місцевості, норми та правила поведінки в природі, недостатньо усвідомлюють зв'язки в природі та цілі екологічної поведінки. Учні прагнуть до збереження об'єктів природи залежно від ситуації; отримують задоволення від спілкування з об'єктами природи; ставляться до окремих із них як до суб'єктів взаємодії; емоційно чутливі до краси окремих об'єктів природи; виявляють інтерес до об'єктів природи. Уміння та навички екологічно доцільної поведінки ситуативні: лише за постановку допоміжних запитань учні можуть здійснити екологічно виправданий вибір; беруть безпосередню участь у збереженні природних об'єктів і їх примноженні здебільшого за дорученням дорослих; наявні фрагментарні дії щодо зменшення витрат природних ресурсів у повсякденному житті.

Прагматичний рівень - учні мають фрагментарні знання про природу своєї місцевості, норми та правила поведінки в природі, недостатньо усвідомлюють зв'язки в природі та цілі екологічної поведінки. Прагнення учнів до збереження об'єктів природи має прагматичний характер (економічна вигода, особиста зацікавленість тощо); вони вибірково отримують задоволення від спілкування з об'єктами природи; ставляться до окремих із них як до суб'єктів взаємодії; об'єкти природи зрідка викликають у них позитивні емоції; виявляють нестійкий, здебільшого прагматичний інтерес до об'єктів природи. Представники цієї групи не мають стійких умінь та навичок екологічно доцільної поведінки: фрагментарні дії щодо зменшення витрат природних ресурсів у повсякденному житті; участь в екологічній діяльності тільки за дорученням дорослих.

Екологічно недоцільний рівень, характерний для учнів, які мають фрагментарні знання про природу своєї місцевості, не володіють знаннями щодо норм і правил поведінки в природі; у них відсутнє усвідомлення зв'язків у природі та розуміння цілей екологічної поведінки. Прагнення учнів до збереження об'єктів природи не спостерігається, вони виявляють байдужість до об'єктів природи; не цікавляться діяльністю з поліпшення довкілля. Об'єкти природи зрідка викликають в учнів позитивні емоції. У них відсутнє прагнення до природоохоронної діяльності; беруть участь в екологічних заходах, наслідуючи однолітків або за дорученням дорослих.

Для обгрунтування необхідності дотримання норм та правил поведінки у природі, аналізу й корекції сформованого в школярів емоційно-ціннісного ставлення до природи, інтересів і потреб звертаємося до екологічної гри.

Беручи до уваги, що гра - найважливіше джерело розвитку довільності поведінки дитини, особлива форма моделювання відношень між дорослими, що фіксуються в правилах певних ролей. Узявши на себе виконання тієї або іншої ролі, дитина керується її правилами, підпорядковує свою поведінку виконанню цих правил (Скрипченко та ін., 2001). Рольова поведінка в грі $\epsilon$ складноорганізованою. У грі $є$ зразок, що спрямовує поведінку дитини й 
виступає еталоном для контролю; виконання дій, визначених зразком; порівняння із зразком, тобто контроль. У грі містяться всі основні компоненти довільної поведінки (Ельконін, 2007).

Гра - це особлива форма активності, діяльності дитини. У ній виявляються ставлення дитини до навколишньої дійсності, до людей, до самої себе. Відомий психолог С. Рубінштейн вважає, що гра - породження діяльності, за допомогою якої людина перетворює дійсність і змінює світ. У грі вперше формується і виявляється потреба дитини змінювати світ (Рубинштейн, 2002). Гра сприяє розвиткові фізичних, інтелектуальних і емоційних якостей молодших школярів. Ігрова діяльність відповідає їх віковим особливостям: емоційність і легка стомлюваність від одноманітності видів діяльності, потяг до фантазії, творчості. Завдяки грі підвищується активність учнів, навчання відбувається швидше, забезпечується міцність знань, формуються комунікативні навички.

Застосовувані в початковій школі дидактичні ігри можуть бути рольовими та іграми з правилами (Савченко, 2002). Рольова гра - це вид гри, у якій діти беруть на себе ролі дорослих і в ігровій ситуації відтворюють їх дії. Роль дорослого містить у собі приховані правила, що регулюють виконання дій із предметами, установлення відношень 3 іншими дітьми відповідно до їхніх ролей. Ігри з правилами - це вид групової гри, у якій дії учасників і їхні взаємовідносини регламентовані правилами, обов'язковими для всіх учасників.

Рольові дії в екологічних іграх головним чином зосереджено навколо норм ставлень між людиною і природою, норм і правил екологічно доцільної поведінки. У грі дитина ніби потрапляє у сферу взаємовідносин людини з природою. Норми і правила, що лежать в основі цих взаємовідносин, стають через гру джерелом формування екологічно доцільної поведінки учнів. Дії під час рольових та імітаційних екологічних ігор зосереджені навколо норм відносин між людиною і природою, норм і правил екологічно доцільної поведінки. Граючи, дитина ніби потрапляє в царину взаємовідносин людини з природою. Норми та правила, що складають їх підґрунтя, стають завдяки грі джерелом формування екологічно доцільної поведінки учнів початкових класів.

Організовуючи експериментальну роботу, з'ясували значення екологічної гри у формуванні вищезазначеної поведінки учнів початкових класів:

- гра сприяє розширенню й поглибленню знань про природу та поведінку в природі;

- гра розвиває здатність передбачати причинно-наслідкові зв'язки в природі й у поведінці;

- гра сприяє накопиченню досвіду щодо вибору взірця поведінки;

- гра формує в дитини потребу екологічно доцільно впливати на природу; 
- гра формує вміння і навички природоохоронної діяльності;

- під час гри формуються й виявляються відповідні переживання щодо об'єктів природи та інтерес до неї;

- гра $€$ ефективним засобом виховання відповідальності за свої вчинки й рішення;

- гра формує позитивне ставлення до об'єктів природи як до суб'єктів взаємодії;

- під час гри формується здатність застосовувати свої знання в різних нових ситуаціях.

В експериментальному дослідженні застосовувалися змагальні, рольові та імітаційні екологічні ігри з метою розширення й поглиблення знань про норми та правила поведінки у природі, встановлення й вивчення взаємозв'язків у природі; формування природоохоронних мотивів, екологічно доцільних дій та вчинків; корекції повсякденної поведінки учнів щодо природи. Запропонований комплекс екологічних ігор спрямований на:

- розширення й поглиблення знань про норми та правила поведінки в природі, установлення і вивчення взаємозв'язків у природі («Знавці природи», «Квітковий хоровод», «Планета загадок», «Майбутнє Землі в наших руках», «У гості до природи», «Про що говорять тварини?» тощо);

- формування природоохоронних мотивів поведінки, навичок природоохоронної діяльності: «У гості до лісу», «Чарівниця вода», «Захистимо Землю!», «Конструкторське бюро майбутнього» тощо;

- корекцію повсякденної поведінки учнів щодо природи («Видра і рибки», «От димар - над ним дим», «Мисливці за Ваттами і Краплями», «Різнобарвна річка», «Дивися, Плането, ми -тут!», «Захистимо Землю!»).

Змагальні екологічні ігри ґрунтуються на стимулюванні активності учасників до набуття й застосування екологічних знань, умінь, навичок (Дерябо, 1999). У даному дослідженні використовуються: ігри з питаннями, загадками, малюнками, кросвордами; екологічні вікторини; ігри-марафони.

Ігри з питаннями й завданнями («Що? Де? Коли?», «Екологічний лабіринт», «У гості до природи», «У злагоді з природою»), загадками («У світі рослин», «У якого дерева такі листочки?», «Квіткова мозаїка», «Планета загадок»), малюнками («Лісові Айболити», «Буквар природи», «Чудолисточки») спираються на ерудицію учнів початкової школи. Наприклад, значна частина описаних у літературі загадок має екологічну спрямованість (Тонке стебло у доріжки, на кінці його - сережки. На землі лежать листки маленькі лопушки. Нам він, як хороший друг, лікує ранки ніг і рук. Подорожник). У них знайшли відображення знання про природу і людину, накопичені протягом століть та тисячоліть. Тому ігри із загадками знайомлять учнів із різномаїттям навколишнього світу, його закономірностями і зв'язками, вчать думати і приймати рішення (Симонова, 2000). 
Учням початкової школи подобається розгадувати доступні для їхнього віку кросворди. Особливо цікавляться вони такими варіантами кросвордів: із малюнками тварин, рослин, позначених номерами («У грибному царстві»), із добиранням загадок, позначених цифрами («Букет квітів»), із завданнями, у яких подані образні, словесні описи рослин, тварин («Лісові дарунки»).

Позитивний емоційний вплив на учнів справляють ігри-вікторини: «Ці кумедні тварини», «У воді та при воді», «Зелена аптека». Екологічні вікторини актуалізують пошук причинно-наслідкових відношень, екологічних взаємозв'язків, спираються на логічне мислення учнів. Наприклад, метою екологічної гри-вікторини «Що в лісі росте? Хто в лісі живе?» є поглиблення й узагальнення знань учнів про рослини, гриби, тварин найближчого оточення, про місця їх існування, правила поведінки школярів у лісі.

Іграм-вікторинам легко надати характер рольових. Наприклад, гравікторина «Ліс - наш спільний дім», проводиться із загадками і відгадками про природні об'єкти - рослини, гриби, тварин, деякі правила збору рослин, поведінки з тваринами в лісі. Кожний учень обирає роль того або іншого природного об'єкта, підбирає загадку і перефразовує від свого імені. Для посилення ігрового ефекту використовуються й деякі атрибути гри: ігрова символіка - шапочки, значки, емблеми.

Екологічні ігри-марафони «Земля - наш дім», «Познайомимося вдруге» проводяться таким чином, що учасники проходять за маршрутом, який складається з етапів-станцій «Ліс», «Зоопарк» тощо. На кожній станції учні виконують завдання, відповідають на запитання, отримують жетони. Перемагає команда, яка отримала найбільше жетонів.

Використання зазначених ігор з питаннями, загадками, малюнками, кросвордами, екологічні вікторини, ігри-марафони виправдовують себе на всіх етапах уроку, на екскурсії, у позаурочній діяльності.

Рольові екологічні ігри ґрунтуються на моделюванні соціального змісту екологічної діяльності: відповідних ролей, системи відношень. У рольових іграх створюються умови уявної ситуації, а учасники грають обумовлені ролі. Такі ігри наближають учасників до умов реального життя (Дерябо, 1999). У дослідженні використовуємо сюжетно-рольові ігри, ігри-імпровізації.

Учні початкової школи задовольняють свої прагнення й потреби спілкування з природою в таких сюжетно-рольових іграх: «Подорож у світ комах», «У гості до лісу», «Казка лісу», «Зайчики і лисиця», «Мисливці за Ваттами і Краплями», «Таємниці лісової стежини».

Ігри-імпровізації («Різнобарвна річка», «Зберігалочка»), екологічні казки («Чарівниця-вода», «Подорож до лісової держави», «Подорож казками») посилюють поетичне сприйняття природи, сприяють її пізнанню, розвивають інтерес, творчі можливості дітей, практичні вміння й навички в природному оточенні, екологічно доцільну поведінку. Гра-імпровізація «Один день із життя юних мандрівників» непомітно вводить дітей у природу, розвиває 
інтерес до природних об'єктів, практичні природоохоронні вміння та навички, екологічно доцільні дії і вчинки. Імпровізована гра викликає інтерес до життя природних мешканців, що позитивно впливає на процес пізнання, на формування екологічно доцільної поведінки, екологічної культури. Ігриімпровізації використовуються на уроках, екскурсіях, прогулянках.

Імітаційні екологічні ігри - це вид екологічних ігор, що ґрунтується на моделюванні екологічної реальності та предметного змісту екологічної діяльності (Дерябо, 1999). У дослідженні використовуємо імітаційні ігри «Ми йдемо лісом», «Пригоди на дорозі», настільне екологічне лото «А-ну, здогадайся!», «Знавці природи».

За часом проведення екологічні ігри поділяються на короткотривалі і довготривалі (Пруцакова, 2002). Короткотривалі займають лише частину уроку («Знавці природи», «У злагоді з природою», «Квіткова мозаїка», «Планета загадок»), довготривалі можна провести протягом одного уроку («Один день із життя юних мандрівників», «Захистимо Землю!», «Конструкторське бюро майбутнього). Більшість ігор, що використовувалися під час експерименту, належать до короткотривалих ігор, оскільки саме вони викликають найбільший інтерес учнів, активізують їхні здібності, збуджують емоції, не надокучають молодшим школярам. Екологічні ігри проводяться як під час уроку, так і на прогулянках, екскурсіях.

У ході експериментального дослідження здійснювалося поточне та заключне вивчення впливу на учнів початкової школи розробленого комплексу екологічних ігор. Поточне вивчення базувалося на спостереженні, бесідах, відгуках учнів початкової школи, учителів, що надавало можливість фіксувати зміни в когнітивній, емоційно-ціннісній, вчинково-діяльнісній сферах особистості.

Так, у процесі проведення екологічних ігор створювалися умови для послідовної активізації вище зазначених сфер особистості молодшого школяра. Зокрема, учень:

- «активізував» емоції - дивувався, переживав, перевтілювався, співчував.

- здобував і переробляв інформацію - від учителя, однолітків, зі спостережень.

- вибирав дію - здійснював пошук рішення проблеми після переживання й одержання інформації; виконував цю дію.

Перевага позитивної інформації та емоцій, обговорення питань і проблем, що можуть бути вирішені за участю дитини - основний педагогічний принцип проведення ігор. Учень переконувався, що він здатен брати активну участь у вирішенні екологічних проблем, надавати допомогу тим, хто її потребує.

Наприклад, в екологічній грі «Вода і я», Крапелька подорожує з хмари у водопровідний кран і далі в каналізацію. Крапельці більше подобається в 
хмарі, озері. Діти дякують Крапельці за їі добрі справи (емоційна сфера). Вода була використана й повинна повернутися до річки. Але стічні води очищаються лише частково, тому що не вистачає станцій очищення (інтелекттуальна сфера). «Ми своїми діями впливаємо на збереження чистоти води. Ми ощадливо витрачаємо воду і вимагаємо цього від інших» (вчинководіяльнісна сфера).

Таким чином, у процесі проведення екологічних ігор молодші школярі свідомо засвоюють правила ощадливого використання води, електроенергії, тепла, поводження з тваринами і рослинами, навчаються поводитися з ними екологічно доцільно, роблять свій посильний, але реальний внесок у вирішення проблеми збереження природи.

Визначення та порівняння сформованості екологічно доцільної поведінки здійснювалося за характеристиками чотирьох рівнів: екологічно доцільного, екологічно ситуативного, прагматичного, екологічно недоцільного.

Ефективність обґрунтованих ігрових технологій засвідчують позитивні зміни в екологічно доцільній поведінці, виявлені в ході експерименту. В експериментальних класах зафіксовано зростання числа учнів, чия поведінка у природі відповідає характеристикам екологічно доцільного й екологічно ситуативного рівнів поведінки. А саме: екологічно доцільний рівень поведінки характерний для 29,6 \% школярів, що на 17,1 \% більше, ніж під час констатувального етапу дослідження, екологічно ситуативний рівень поведінки виявися у 40,4 \% учнів, що на 8,4 \% більше, ніж у констатувальному етапі експерименту. Водночас відбулося зменшення кількості учнів із прагматичним та екологічно недоцільним рівнем поведінки. Прагматичний рівень поведінки характерний для 25,2\% учнів (проти 35,3\% під час констатувального етапу експерименту), екологічно недоцільний рівень поведінки - у 4,8\% учнів (проти 20,2\% у констатувальному етапі дослідження).

Позитивні якісні зміни у формуванні екологічно доцільної поведінки спостерігалися також за певними зовнішніми проявами: підвищенням інтересу до участі в екологічній діяльності, прагненням зберігати та охороняти природу, зростанням ініціативи щодо взаємодії з природою, особистої причетності до цієї важливої справи.

Висновки та перспективи подальших наукових розвідок. У даному дослідженні доведено ефективність комплексу екологічних ігор змагальних, рольових та імітаційних, що базуються на навчальному матеріалі з метою:

- розширення й поглиблення знань про норми та правила поведінки в природі;

- корекції повсякденної поведінки учнів початкової школи щодо природи;

- формування природоохоронних мотивів поведінки. 
Запропоновані ігрові технології впливають на емоційну, діяльнісну тамотиваційну сферу особистості молодшого школяра. Розроблені екологічні ігри дозволяють аналізувати й коригувати сформовані екологічні ціннісні орієнтації, інтереси та потреби; формувати особисте ставлення до екологічних проблем. Застосування комплексу екологічних ігор сприяло формуванню знань учнів про норми та правила поведінки в навколишньому середовищі, зв'язки та залежності в природі, емоційно-ціннісного ставлення до природи, що є важливим регулятором дій і вчинків учнів у природі. Учні набули певного досвіду екологічно доцільної поведінки.

Результати діагностування рівнів сформованості екологічно доцільної поведінки учнів початкової школи дозволили переконатися в ефективності визначених і апробованих ігрових технологій та підтвердити їх вплив на формування визначених нами структурних компонентів екологічної поведінки учнів.

Проведене дослідження не вичерпує всіх аспектів проблеми виховання екологічно доцільної поведінки учнів початкової школи. Потребує детальнішого дослідження проблема формування екологічно доцільної поведінки як чинника соціалізації учнів початкової школи.

\section{ЛITЕРАТУРА}

Бобик, О. І., Беречова, Г. І., Копитко, Б. І. (2007). Теорія ймовірності та математична статистика. Київ: ВД «Професіонал» (Bobyk, О. І., Berechova, Н. І., Kopytko, В. I. (2007). Probability theory and mathematical statistics. Kyiv: "Professional").

Дерябо, С. Д. (1999). Экологическая психология: диагностика экологического сознания. Москва (Deriabo, S. D. (1999). Ecological psychology: diagnostics of ecological consciousness. Moscow).

Пруцакова, О. Л. (2002). Формування основ екологічної культури учнів 5-8 класів засобами дидактичної гри (автореф. дис. ... канд. пед. наук: 13.00.07). Київ (Prutsakova, O. L. (2002). Formation of bases of ecological culture of pupils of 5-8 grades by means of didactic game (PhD thesis abstract). Kyiv).

Рубинштейн, С. (2002). Основы общей психологии. СПб.: Питер (Rubinshtein, S. (2002). Fundamentals of General Psychology. SPb.).

Савченко, О. (2002). Дидактика початкової школи. Київ, Україна: Генеза (Savchenko, 0. (2002). Primary school didactics. Kyiv).

Сбруєва, А. А., Колишкіна, А. П. (2018). Progamme-methodological support of school and family interaction in the formation of the pupils' of primary school environmentally expedient behavior. Педагогічні науки: теорія, історія, інноваційні технології, 3 (77), 240-255 (Sbruieva, A. A., Kolyshkina, A. P. (2018). Progamme-methodological support of school and family interaction in the formation of the pupils' of primary school environmentally expedient behavior. Pedagogical sciences: theory, history, innovative technologies), 3 (77), 240-255).

Скрипченко, О., Долинська, Л., Огороднійчук, 3. та ін. (2001). Вікова та педагогічна психологія. Київ, Україна: Просвіта (Skrypchenko, O., Dolynska, L., Ohorodniichuk, Z. et al. (2001). Age and pedagogical psychology. Kyiv). 
Симонова, Л. П. (2000). Экологическое образование в начальной школе. Москва: Академия (Simonova, L. P. (2000). Environmental education in elementary school. Moscow: Academy).

Эльконин, Д. (2007). Детская психология. Москва: «Академия» (Elkonin, D. (2007). Child psychology. Moscow: Academy).

\section{PEЗЮME}

Колышкина Алла, Врадий Екатерина. Использование игровых технологий в формировании экологически целесообразного поведения учащихся начальных классов.

В статье решается проблема экологического воспитания учащихся начальных классов. Цель исследования заключается в обосновании эфрфективности использования игровых технологий в формировании экологически челесообразного поведения учащихся начальных классов. Для достижения цели публикации использованы методы исследования уровней экологического поведения учащихся начальной школы в природе, состоящие из следующих компонентов: 1) создание воображаемых ситуаций с помощью серий заданий; 2) создание реальных ситуаций выбора образца поведения учащихся начальной школы в природе; 3) наблюдение за поведением учащихся в природе. Разработаны соревновательные, ролевые и имитационные экологические игры, основанные на учебном материале, предлагаемом школьной программой. Доказано, что игра экологического содержания способствует реализации поведенческого потенциала ребенка в природе, обеспечивает осмысление собственной деятельности в природе. Перспективы дальнейших научных исследований связаны с проблемой формирования экологически челесообразного поведения как фрактора социализации учащихся начальной школы.

Ключевые слова: экологически челесообразное поведение, экологическое воспитание, дидактические игры, ролевые экологические игры, имитационные экологические игры, ученики начальной школы, уровни экологического поведения, поведение.

\section{SUMMARY}

Kolyshkina Ala, Vradi Kateryna Use of game technologies in formation of environmentally expedient behavior of the primary school pupils.

The article reveals the issue of environmental education of the primary school pupils. The aim of the study is to substantiate the effectiveness of the use of game technologies in the formation of environmentally expedient behavior of the primary school pupils. In order to achieve the purpose of the publication, we used the methodology of studying the levels of environmental behavior of the primary school pupils in nature, which consists of the following components: 1) creation of imaginary situations through a series of tasks; 2) creation of real situations of choice of a behavior model of the primary school pupils in nature; 3) observation of pupils' behavior in nature. The levels of environmentally expedient behavior (environmentally expedient, environmentally situational, pragmatic and environmentally unexpedient) that serve as a basis for experimental study are characterized. The level of environmental behavior of the primary school pupils in nature was determined for each task according to the corrected formula of $G$. Witzlak. The importance of game technologies for observing the rules of behavior in nature, analysis and correction of pupils' emotional-value attitude to nature, interests and needs are substantiated. Competitive, roleplaying and simulation environmental games have been developed with the aim of expanding and deepening knowledge on the rules of behavior in nature, establishing and studying relationships in nature; formation of environmental motives, environmentally expedient actions and deeds; correcting pupils' daily behavior in nature. Implemented environmental games are based on the training material offered by the school curriculum. In 
the course of the experimental research was carried out current and final study of the impact on the primary school pupils of the developed set of environmental games, which was based on observation, conversations, feedback from the primary school pupils, teachers, which provided the opportunity to capture changes in cognitive, emotional-value and activity spheres of the personality. It is proved that game of ecological content contributes to realization of the child's behavioral potential for nature, provides an understanding of his/her own activities in nature. In the experimental classes there was recorded an increase in the number of pupils whose behavior in nature corresponds to the characteristics of environmentally expedient and environmentally situational levels. Prospects for further research are related to the study of the issue of formation of environmentally expedient behavior as a factor in socialization of the primary school pupils.

Key words environmentally expedient behavior, environmental education, didactic games, role-playing environmental games, imitation environmental games, primary school pupils, levels of environmental behavior, behaviour.

\section{удк 373.3.011.33.026(045)}

Олена Муращенко

Комунальний заклад «Запорізький обласний інститут післядипломної педагогічної освіти»

Запорізької обласної ради

ORCID ID 0000-0002-5887-1752

DOI 10.24139/2312-5993/2019.08/098-108

\section{ДИДАКТИЧНИЙ АСПЕКТ ФОРМУВАННЯ МІЖПРЕДМЕТНОЇ СТРУКТУРИ НАВЧАЛЬНИХ ЗНАНЬ ТА СПОСОБІВ ДІЙ УЧНІВ В ОСВІТНЬОМУ ПРОЦЕСІ ПОЧАТКОВОї ШКОЛИ}

у статті представлено й теоретично обгрунтовано систему міжпредметних зв'язків у контексті дидактичного аспекту їх застосування в початковій школі, проаналізовано різні підходи до визначення даних зв'язків у дослідженнях вітчизняних і зарубіжних науковців, розглянуто комплекс умов, які сприяють ефективному формуванню міжпредметної структури навчальних знань та способів дій учнів, здійснено структурний аналіз функцій міжпредметних зв'язків, зокрема проаналізовано діалектичну, логічну, психологічну та дидактичну їх властивість. Автором передбачено перспективу подальших досліджень в апробачії презентованих шляхів здійснення міжпредметних зв'язків в освітньому процесі системи початкової школи.

Ключові слова: міжпредметні зв'язки, дидактичний аспект, інформачійний шлях здійснення, перенесення прийомів дій міжпредметної властивості, пошукові творчі роботи, дослідницький етап, проблема, початкова освіта.

Постановка проблеми. Важливим механізмом розвитку наукового пізнання $€$ взаємодія об'єктів навколишнього світу, виділення суттєвих зв'язків і встановлення відношень між ними. Взаємозв'язки між предметами та явищами світу утворюють в кожній цілісній системі внутрішню структурну єдність всіх їі елементів і властивостей та виявляють 